\title{
Glucosulfone Free Acid
}

National Cancer Institute

\section{Source}

National Cancer Institute. Glucosulfone Free Acid. NCI Thesaurus. Code C87218.

A sulfone drug that is converted to dapsone in the body. It has been used to treat mycobacterial infections, including tuberculosis and leprosy. 